\title{
Historical Note
}

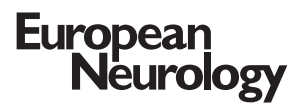

Eur Neurol 2016;76:175-181

DOI: $10.1159 / 000450605$

Received: August 3, 2016

Accepted: September 3, 2016

Published online: September 23, 2016

\section{Sydenham on Hysteria}

\author{
John M.S. Pearce \\ Department of Neurology, Hull Royal Infirmary, Kingston upon Hull, UK
}

\section{Key Words}

Sydenham · Hysteria - Dissertatio epistolaris - Dissociation . Somatoform disorder

\begin{abstract}
This historical essay outlines early ideas and clinical accounts of hysteria. It reproduces verbatim parts of a remarkable text of Thomas Sydenham. This provides the most detailed description of hysterical symptoms, contemporary treatment and particularly Sydenham's opinions about the nature of the disorder. His portrayal is compared to later and modern concepts and classification.

(c) 2016 S. Karger AG, Base
\end{abstract}

From the time of Greco-Roman Medicine, the uncertain nature of hysterical illness was a fertile source of controversy. Because there were no testable objective signs of disease, the diverse ideas relating hysteria to the uterus, psychological and physiological causes created persisting polemics. Theories fluctuated chaotically, influenced by social changes of prosperity or deprivation, contemporary attitudes and issues of gender.

Charcot (1825-1893) between 1872 and 1878 demonstrated a bewildering, theatrical spectrum of hysterical manifestations to awestruck audiences. Before Charcot, the varied symptoms were known [1] but there was little prescience of our ideas of conversion, dissociation and somatoform disorders with somatic symptoms and re- lated disorders (DSM-V). Edward Jorden (1569-1632) in 1603 had written an important discourse [2] that dispelled supernatural and demonic agencies. Charcot's many predecessors, from Cheyne [3] to Sydenham and Willis [4] in the 17th century to Pinel [5], Briquet [6] and Bourneville [7] in the 19th century, conditioned and influenced his controversial studies on hysteria [1].

Thomas Sydenham (1624-1689; fig. 1) is renowned for many contributions to descriptive clinical Medicine that included podagra (gout), chorea sancti viti (St. Vitus' Dance), infectious fevers, chlorosis (iron deficiency anemia) and hysteria. His thoughts on hysteria are therefore of interest. I include unadulterated quotations to show both his observations and deductions.

Sydenham was descended from an ancient Somerset family, one branch of which moved to Dorsetshire at Wynford Eagle (fig. 2), where he was born in the reign of Henry VIII. He died of gout and renal disease in Pall Mall, London, on 29 December, 1689. Sydenham studied Medicine at Magdalen Hall, Oxford. His studies were interrupted by his participation on the parliamentary side during the first of the English Civil Wars. He transferred to Wadham College and received his MB on 14 April, 1648. He was elected Fellow of All Souls in 1651, and began to

Captions: I believe these images are in the public domain because they originated in a country with a copyright term of life of the author plus 100 years or less. The images are also in the public domain if taken in a country that does not accord copyright to non-artistic photographs of Public Domain works, such as the United States.

\section{KARGER}

E-Mail karger@karger.com

www.karger.com/ene
(C) 2016 S. Karger AG, Basel

0014-3022/16/0764-0175\$39.50/0
John M.S. Pearce, MD, FRCP

Emeritus Consultant Neurologist, Department of Neurology

304 Beverley Road Anlaby

East Yorks, Kingston upon Hull HU10 7BG (UK)

E-Mail jms.pearce@me.com 
practise about 1655 in London, where he studied infectious epidemics. This culminated in his book on fevers, Methodus Curandi Febres (1666), later expanded into Observationes Medicae (1676). Its preface of 35 pages expounded important general principles for the practice of medicine; it became a standard textbook for two centuries.

Sydenham had close friends of great distinction. John Locke (1632-1704), was one of England's most distinguished philosophers. He influenced Sydenham's probative methods and probably contributed to the preface of Observationes Medicae [8]. It begins with a dedication to John Mapletoft (1631-1721), and included a handsome tribute to Locke, who like Sydenham, came from a West Country Puritan family. Sydenham was also a neighbor in Pall Mall of Robert Boyle's (1627-1691) sister, Lady Ranelagh, in whose house was Boyle's laboratory. It was Boyle who suggested to Sydenham the subject of his first book, Methodus Curandi Febres, on the treatment of fevers. Sir Hans Sloane was one of his many distinguished students and became President of the College of Physicians and of the Royal Society.

Recognized as a pioneer of clinical medicine and epidemiology, Sydenham's emphasis on detailed observations of patients and scrupulous records was to be the foundation of modern clinical methods, on the basis of which he has been called 'the English Hippocrates'. His pioneering of quinine was of immense benefit in fevers notably malaria - and innumerable lives were saved by his cooling regimen in the treatment of smallpox. He used iron in the treatment of chlorosis, and he realized the value of opium, which he gave as laudanum [11]. Despite his immense skill, he was never appointed to a major hospital nor elected a Fellow of either the College of Physicians or the Royal Society.

Joseph Frank Payne provides an excellent summary and biography of Sydenham [9]. Other notable biographies are those of Latham [10] and Dewhirst [11]. But for a deeper insight into his character and his high moral beliefs, the work of Bettany should be consulted [12].

\section{Hysteria}

Responding to the pleas for advice of a country physician, Dr. William Cole of Worcester, in 1681, Sydenham wrote a letter [13] entitled: Dissertatio epistolaris ad spectatissimum doctissimumque virum Gulielmum Cole, $M D$, de observationibus nuperis circa curationem variolarum confluentium, nec non de affectione hysterica. Lindaviae:

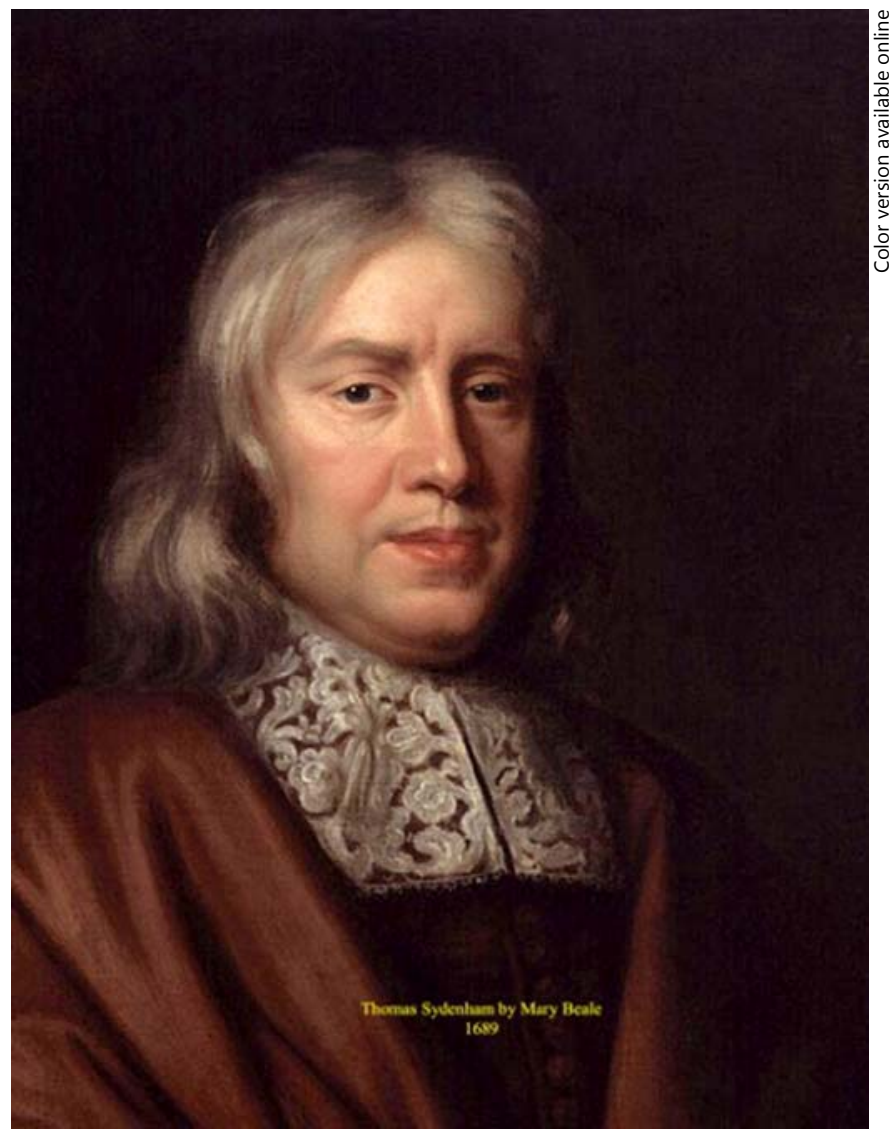

Fig. 1. Thomas Sydenham by Mary Beale. National Portrait Gallery: NPG 3901. This work, originally in 1st edition of Observationes Medicae 'is in the public domain'.

Typis Theodori Hechtii, 1683. (Dissertation of a letter to a highly distinguished and learned man, William Cole, $\mathrm{MD}$, on recent observations about the treatment of confluent smallpox and also of the affection of hysteria.)

The first part concerned the treatment of smallpox. The second part related to hysteria, which was considered one of his most important and original works [14, 15] (fig. 3). His description shows notions, which in several aspects differ from those both of earlier and later physicians.

On pp. 302-305, he describes the attributes of hysteria. 'This disease, most frequently occurs of all chronic diseases: one half, of all chronic diseases;' - this he estimates as one-sixth of all human maladies. He says:

'women, except for those who lead a hardy and robust life, are rarely quite free from it; those men who lead a sedentary or studious life are subject to the same complaint; in their case, it is indeed called hypochondria, but this disease is as like hysteria as one egg is like another. Men are less subject to it than women because of their more robust habit of body.' 


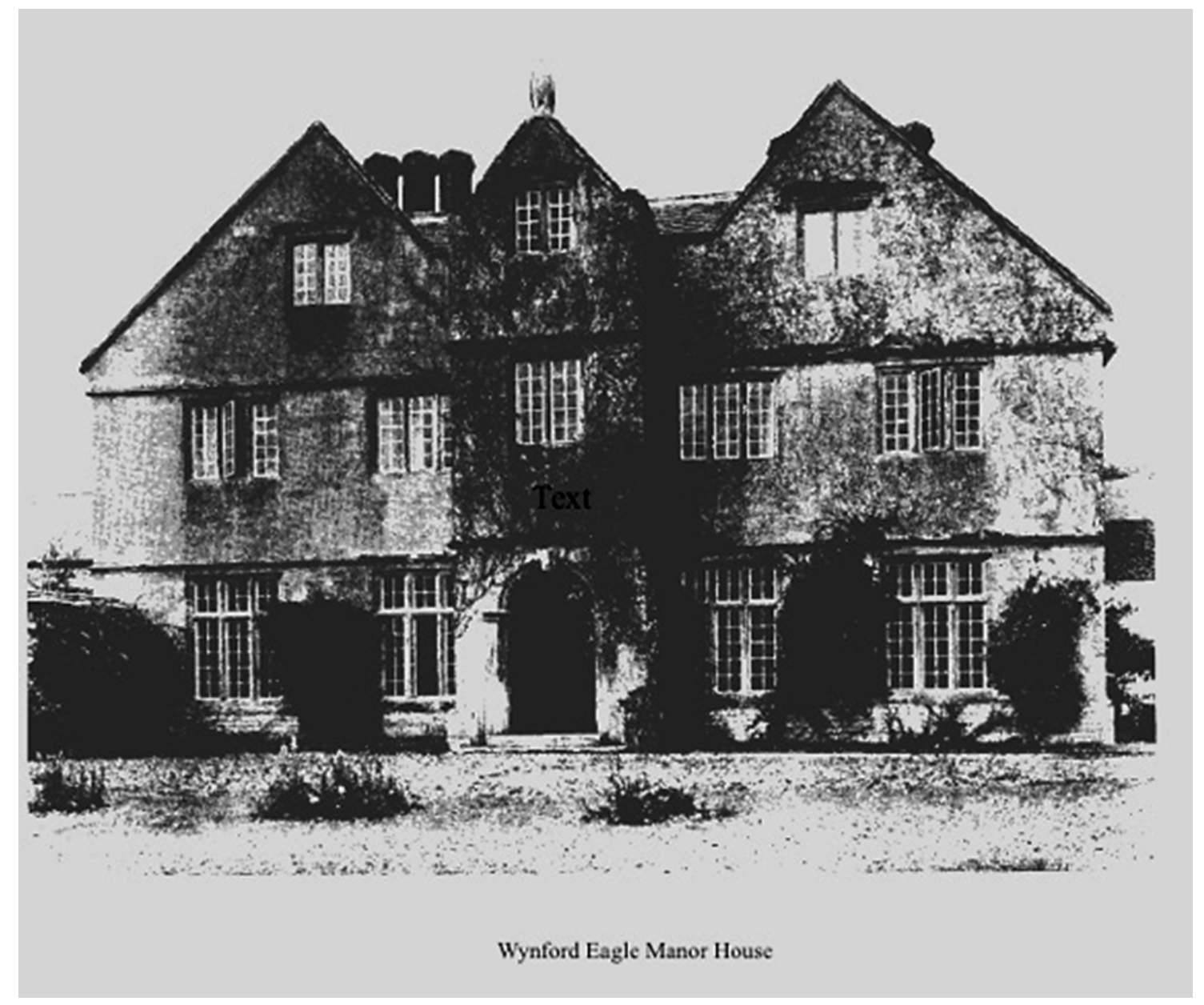

Fig. 2. Wynford Eagle Manor House.

'It resembles almost all the diseases poor mortals are inclinable to, for in whatever part it seats itself, it presently produces symptoms as belong to it, and unless the physician is very skillful, he will be mistaken and will think those symptoms come from some essential distemper of this or that part and not from any hysteric disease.' [15]

Unlike his contemporaries, Sydenham systematically detailed the many and diverse symptoms of hysteria. Gowers reiterated this in the 19th century,

'... Symptoms of almost every other disease of the nervous system, since there is scarcely one which may not be simulated by this protean malady.' [16]

\section{Sydenham's description includes,}

'For instance, sometimes it possesses the head and causes an apoplexy, which also ends in hemiplegia, with the cortex of the brain being stuffed by a great deal of phlegm: ... often presently after delivery...or a hard labor...'

'Sometimes it occasions violent convulsion, much like the falling sickness, the belly and bowels swelling toward the throat, the sick struggling so violently, that though at other times her strength is but ordinary she can now scarcely be held by all the strength of those that are about her, and she mutters some odd and inarticulate sounds and strikes her breast...commonly called mother fits....' (p. 441)

'Sometimes it seizes the outward part of the head between the pericranium and skull causing violent pain continually fix' $d$ in one part, which may be covered by the top of your thumb and violent vomiting accompanies this pain. I call this kind clavus hystericus, afflicting those that have a chlorosis.' (p. 441)

'Sometimes falling on the vital parts, it causes a beating of the heart.... Sometimes it seizes the lungs, and the patient coughs almost without intermission, but expectorates nothing...' (p. 441)

'Sometimes rushing violently on the region under the scrobiculum cordis, ${ }^{1}$ it produces violent pain, very like the iliac passion, and the woman vomits greatly... and reaching to vomit for many days, at length the fit is carry'd off by a violent jaundice...' (p. 442) [15]

\footnotetext{
${ }^{1}$ The depression, just below the lower end of the sternum.
} 


\section{T H E \\ WHOLE WORKS \\ Of that Excellent}

Practical Phyfician,

Dr. Thomas Sydenbam :

W H E R E I N

Not only the HIS T ORY and CURES of Acute Difeafes are treated of, after a New and Accurate Method; but alfo the Shorteft and Safeft Way of Curing molt Chronical Difeafes.

Fig. 3. The whole works of that excellent practical physician, Dr. Thomas Sydenham: 1742.

ebe Deventb evition:

Corrected from the Original Latin, By Joh N PEChey M. D. Of the College of Phyficians in London.

$$
\text { IONDON, }
$$

Printed for M. Wollingtion, and Sold by Daniel Browne, Andrew Bell, Fobn Darby, Arthwr Betsefworth, Fohn Pemberton, Charles Rivington, Fohn Hooke, Thomas Cox and Comp. For. Battley, and Edward Symon. M.DCC.XVII. 
In a lengthy account, he also describes symptoms afflicting the bladder, stone in the kidneys, stomach and guts.

'And as the disease afflicts almost all the inward parts, sometimes the outward parts are also seized by it, and the musculous flesh occasioning pain and sometimes a tumor in the jaws, shoulders, hands, thighs, legs... in this tumor, there is swelling in the morning; neither does it yield to the finger nor leave any mark [pitting] behind it;...' (p. 443)

'Moreover, the sick are oppressed by dreadful anguish and wholly despair of recovery with dejection of soul; a certain desperation accompanies (as I have noted) these kind of hysterical diseases as the pain and vomiting mentioned above.' (p. 442)

'Lastly, it is known to everyone that hysterical women sometimes laugh excessively, and sometimes cry as much, without cause for either.... But among all the symptoms that accompany this disease, this is the most proper and almost inseparable, viz. urine as clear as rock-water, and this hysterical women evacuate plentifully,... the pathognomonic sign of this disease...' (p. 444)

As to its nature, he said it all depends upon an 'ataxia' or disturbance of the 'animal spirits,' [cf. Galen's 'psychical pneuma' or breath of the soul] which rushing down upon the various organs of the body, excite pain and spasm, and in short 'create the proper symptoms of that part.'

\section{He continues:}

'in both the firmness of the spirits being wanting, which is always to be found in the robust and in those who are continually strengthened by the assistance of vigorous spirits, they cannot bear the impressions of cross accidents, but are soon moved by anger or pain, and are apt to be angry, as those to whom either nature has given a soft and weak governing of mind, or it has been rendered so by a long series or continuance of diseases. For the strength and constancy of mind, as long as it is confined by the body, much depends on the firmness of the spirits that are subservient to it... And this truly is the condition of these miserable and dejected people we have described.'

\section{Sydenham concludes,}

'that these animal spirits are not rightly disposed, and not by seed and menstrous blood corrupted, nor from depravation of the juices or congestion of acrid humors, but from those causes we have assigned.' Yet, he confesses (p. 453), 'The confusion of the spirits, the cause of this disease, occasions putrid humors in the body, by reason the function as well as of those parts which are distended by the violent impulse of the spirits as of those deprived of them is wholly perverted.'

He carefully modified his treatments according to the patients' (constitutional) strength or perceived weakness. He ordered the sick to be bled from the arm and after that to be purged three or four mornings following. Remedies commonly called Anti-Hystericks were used to comfort the blood and animal spirits (p. 318). He prescribed eight ounces of blood taken from the right arm, then galbanum or other herbal purgatives (p. 319) followed by filings of steel, extract of wormwood, castor and rue pills or chalybeate ${ }^{2}$ and laudanum every night. Such remedies reflect the general tools of therapeutics at the time. After these evacuations, Sydenham aimed at strengthening the blood with chalybeate for 30 days. He also referred to many other remedies including laudanum, which were applied generally for epidemic diseases in his time. He advocated waters impregnated with the mine, iron and steel. 'But nothing does so much comfort and strengthens the blood and spirits as much as riding horseback every day for a long while.' His writings give the impression of a wise, thoughtful but conservative physician. 'When no manifest indication pointed out to me what should be done, I have consulted my patients' safety and my own reputation most effectually by doing nothing at all.'

\section{Discussion}

Historically, theories of hysteria can be simplified [1]: - Greco-Roman Medicine marked the 'wandering womb';

- In the Middle ages, it was caused by daemonic possession;

- The 17th century favoured a neurological disorder;

- The Enlightenment saw the recurrence of uterine causes in the 'furies' of the womb;

- In the late 19th century, Charcot resurrected ideas of a brain disorder but its delineation was incomplete.

A few years before Sydenham, Thomas Willis [17] and the French physician, Lepois [18], thought that hysteria might be applicable to men, 'given its lodging in the nervous stock, spanning the brain and the spinal cord.' (Willis) This view derived from the prevalent theory of 'sympathies'.

Sydenham's writings on psychological disorders have been extensively reviewed by Veith [19] and by Schneck [20]. His account of hysteria is a lengthy one, and if at times it appears repetitive it did convey a fresh approach with clear descriptions of its manifestations and an informed discussion about causative and precipitating factors in etiology and an appraisal of contemporary management. Like Edward Jorden (1569-1632) [2], he dispelled notions of demonic possession, divine affliction and witchcraft. He plainly indicated the fragility of personality and the lack of robustness as essential predispos-

${ }^{2}$ Chalybeate water, derived from sandstone was a solution of ferrous bicarbonate. 
ing factors. This was a relatively new idea. He also clearly implicated psychological factors in causation: the dejection, dreadful anguish of mind and despair of recovery. Yet the mechanisms of production of symptoms Sydenham suggests are organic or physiological:

'The cause of this disease occasions putrid humors by reason that the function as well as those parts which are distressed by the violent impulse of the spirits, or by putrefying juices heaped up in the blood (p. 314). Remedies commonly called anti-hysterics were used to comfort the blood and animal spirits.' (p. 318)

'Bloodletting and herbal purgatives were the mainstay of many treatments, but Sydenham, showing his wisdom and pragmatic discernment, conceded that by a certain idiosyncrasy some women are thereby much injured and they must not be prescribed.' (p. 321)

Two more modern classic papers show that the arguments of Sydenham's times remain unsolved. Eliot Slater (1904-1983) rejected hysteria as an entity, concluding, 'the diagnosis of 'hysteria' is a disguise for ignorance and a fertile source of clinical error. It is in fact not only a delusion but also a snare' [21]. Sir Francis Walshe's (18851973) elegant critique [22] of Slater's position stated, 'Nevertheless, Slater's nihilism in regard to hysteria is a challenge to neurologists once again to justify the concept of hysteria as a nosological entity in its own right... Its essential difference from somatic disease is that it constitutes a behavior disorder, a human act, on the psychological level.' Slater's view was later contradicted by follow-up studies [23], which showed that the diagnosis of hysteria is reliable and very few patients develop neurological sequelae at follow-up.

The recent concept of hysteria or conversion disorder, based on Freud's psychoanalytic theory [24], rests on the emergence of physical symptoms with inhibition of neural networks as an unconscious attempt to resolve a painful psychic conflict. But as with the ideas so ably portrayed by Sydenham, there are unexplained issues. It is difficult to establish what amounts to a 'sufficient' psychological stressor. It is also hard to distinguish unconscious motivation from conscious simulation or feigning of symptoms, which often yield personal and social advantages in providing a sick role for its subject [25]. The chaotic swinging of concepts and definitions is again evident in the most recent DSM-V criteria. Hysterical dissociation disorder is now roughly equated to a functional neurological disorder that requires 'positive neurological symptoms.' It is now seen as neurological rather than psychiatric in nature - an odd change in labels, but not new objective observations. This accords with Sydenham's concentration on somatic symptoms, and as in DSM-V, he did not require unconscious motivation, a notion developed after his time, notably by Freud. Paradoxically, hysteria is no longer a 'psychiatric' condition; yet, once neurologists have diagnosed functional neurological disorder they still continue to refer the patient to psychiatric colleagues [26].

The subject of hysteria has reflected attitudes about health, religion, class and gender. Investigations to unravel its knotted psychological and physiological complexities are likely to occupy doctors for years to come. Sydenham obtained greater recognition on the Continent than in Britain. Nevertheless, the great Hermann Boerhaave is said to have never referred to him without raising his hat.

\section{Disclosure Statement}

There are no conflicting interests or financial support in this work. This paper is not under consideration by another journal.

\section{References}

1 Pearce JMS: Hysteria before Charcot; in Bogousslavsky J (ed): Hysteria: The Modern Birth of an Enigma. Frontiers of Neurology and Neuroscience, pp 1-11. www.karger.com/ fnene.

2 Jorden E: A brief discourse of a disease called the suffocation of the mother, 1603; in Brain L: Doctors Past and Present. London, Pitman, 1964, p 29.

3 Cheyne G: The English Malady: or, a Treatise of Nervous Diseases of All Kinds, as Spleen, Vapours, Lowness of Spirits, Hypochondriacal, and Hysterical Distempers, Etc (London and Bath: G. Strahan and J. Leake, 1733) Edited by R. Porter. Routledge: London. 1990.
4 Willis T: Practice of physic. Being the whole works of that renowned and famous physician. (English transl by S. Pordage) London, 1684, p 69; in Spillane JD: Doctrine of the Nerves. Oxford, Oxford University Press, 1981, p 72.

5 Philippe P: Nosographie Philosophique, ed 3. Paris, J. A. Brasson, 1807, vol 2, pp 279-286.

6 Briquet P: Traité Clinique et Thérapeutique de L'hystérie, Paris, J.-B. Baillière, 1859, pp $11-12$.

7 Bourneville DM, Régnard P: Paris: Bureau du Progrès Médical; Iconographie photographique de la Salpêtrière, Service de M. Charcot. Paris: Bureau du Progrès Médical et V. Adrien Delahaye et Cie, 1877.
8 Meynell GG: John Locke and the preface to Thomas Sydenham's Observationes medicae. Med Hist 2006;50:93-110.

9 Payne, Joseph Frank. (2013). Thomas Sydenham. 1900. Reprint. London: Forgotten Books, 2013, pp 140-141. (Original work published 1900) The whole works of that Excellent practical physician Dr. Thomas Sydenham. London, printed for Richard Wellington. 1696. https://books.google.co.uk/books?id = SJNkAAAAcAAJ.

10 Latham RG: The works of Thomas Sydenham, MD, trans. from the Latin, 2 vols. London, Sydenham Society, 1850, vol 2, pp 85-99. Reprinted in facsimile in 1970 (Classics of Medicine Library, Birmingham, Alabama). 
11 Dewhirst K: Thomas Sydenham (1624-1689): His Life and Original Writings. London, Wellcome Historical Medical Library, 1966.

12 Bettany GT: Eminent Doctors. Chapter 111. Thomas Sydenham, The British Hippocrates, ed 2. London, John Hogg, 1885, pp 52-70.

13 Sydenham T. Epistolary Dissertation to Dr. Cole. Presentation copy in the College of Physicians dated March 21, 1681-1682.

14 Boss JM: The seventeenth-century transformation of the hysteric affection, and Sydenham's Baconian medicine. Psychol Med 1979; 9:221-234.

15 Pechey John: The whole works of that excellent practical physician, Dr. Thomas Sydenham, ed 8: Corrected from the Original Latin.
London: Printed for J. Darby for M Poulson, and sold by A. Bettesworth and F. Clay. MDCCXXII (1722).

16 Gowers W: A Manual of Diseases of the Nervous System, ed 1. London, Churchill 1888, p 935.

17 Willis T: An Essay of the Pathology of the Brain and Nervous Stock. London, J.B. for T. Dring..., 1681; [4], 106: 90

18 Lepois C. cited by Cumston CG. Journal of Nervous \& Mental Disease 1923;58:426-430.

19 Veith I: On Hysterical and Hypochondrial Afflictions. Bull Hist Med 1956;30:233-240.

20 Schneck JM: Thomas Sydenham and psychological medicine. Am J Psychiatry 1957;113: 1034-1036.
21 Slater E: Diagnosis of 'hysteria'. Br Med J 1965;1:1395-1399.

22 Walshe F: Diagnosis of Hysteria. Br Med J 1965;2:1451-1454.

23 Crimlisk HL, Bhatia K, Cope H, David A, Marsden CD, Ron MA: Slater revisited: 6 year follow up study of patients with medically unexplained motor symptoms. BMJ 1998;316: 582-586.

24 Freud, Sigmund (1962): The Standard Edition of the Complete Psychological Works of Sigmund Freud: Volume III (1893-1899). London, Hogarth Press, pp 203-204.

25 Ron M: Explaining the unexplained: understanding hysteria. Brain 2001;124:1065-1066.

26 Ron MA: Personal communication, 2016. 